
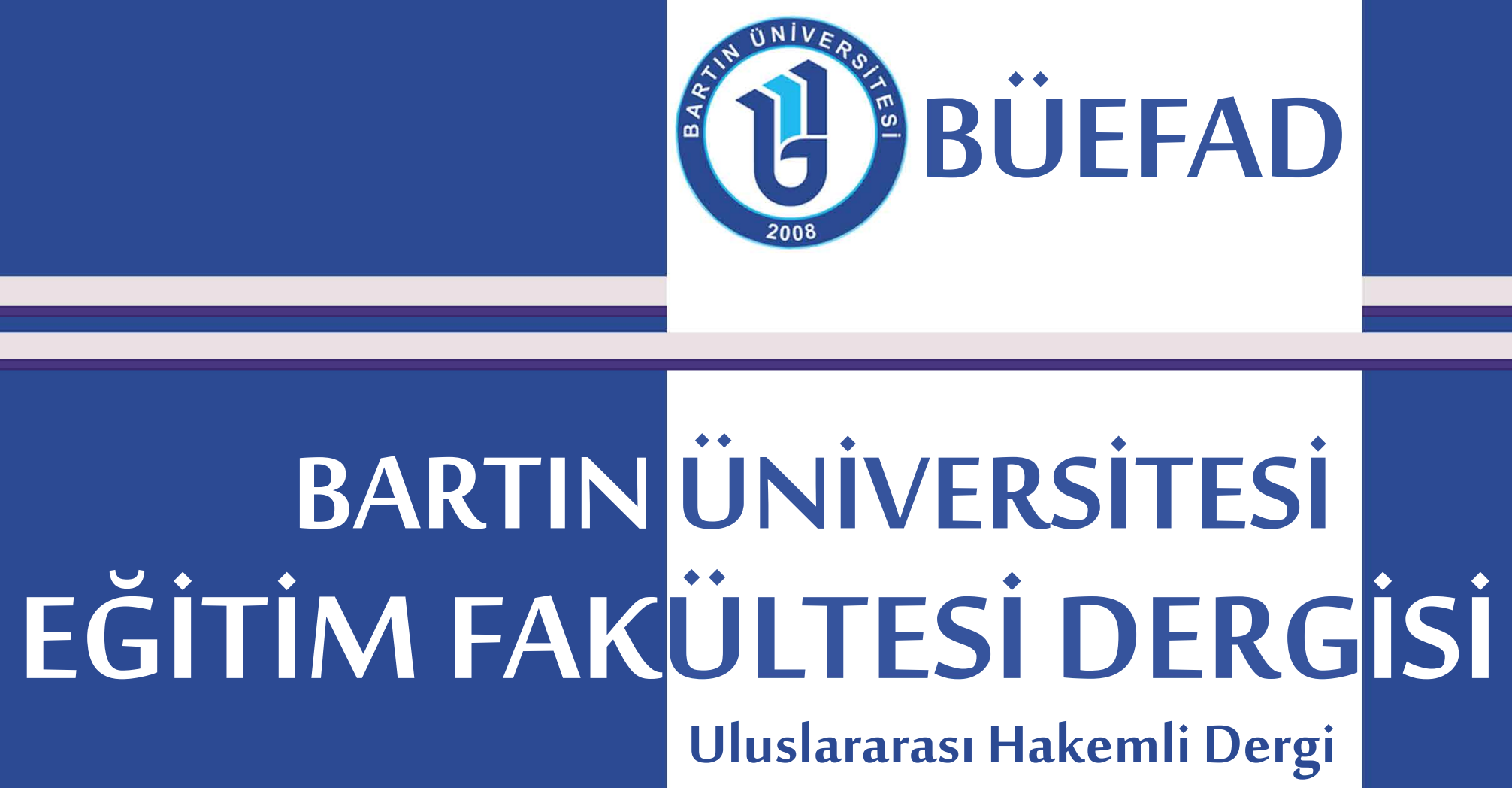

\section{- AYRI BASIM -}

Arş. Gör. Dr. Osman ÇİMEN

Prof. Dr. Mehmet YILMAZ

Dönüşümsel öğrenme Kuramına Dayalı Cevre Eğitiminin Biyoloji Öğretmen Adaylarının Çevre Sorunlarına Yönelik Algularına Etkisi

\section{- SPECIAL EDITION -}

RA Osman CIMEN

Prof. Mehmet YILMAZ

The Influence of Transformative Learning Based Environmental Education on Preservice Biology Teachers' Perception of Environmental Problems
BARTINUNIVERSITY JOURNAL

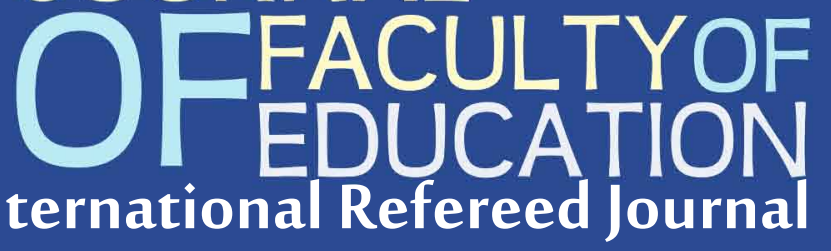

Cilt/Volume: $3 \quad$ Sayı/Issue: 1

Yaz/Summer 2014 ISSN 1308-7177
ProcessForm

Objectives

Pre-Service

okuma 1 echnology

Profession

Verbal Supervision

Understanding

Study Investigating Turkish

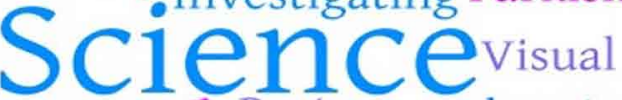

Iอ

Candidatest

Education Approaches ölçeğinin

Digital Supervisors

Teacher Mathematics Profiles

Examination Processing

Assisted Reliability Alg1sı

ÖzyeterlilikEleștirel

Attitudes ${ }^{\text {Style }}$

2014-3

Teaching Features University

Güvenirlik Geçerlilik

Çalışması Analysis

Example Speech 


\section{BARTIN ÜNIVERSİTesi EĞítim FAKüLTESI DERgisi}

BARTIN UNIVERSITY JOURNAL OF FACULTY OF EDUCATION

Cilt/ Volume: 3, Say1/Issue: 1, Yaz / Summer 2014

ISSN:1308-7177

\section{$\underline{\text { Sahibi }}$}

Bartın Üniversitesi Eğitim Fakültesi Adına Prof. Dr. Firdevs GÜNEŞ (Dekan)

Editör

Yrd. Doç. Dr. Sedat BALYEMEZ

\section{Alan Editörleri}

Doç. Dr. Çetin SEMERCi

Doç. Dr. Necati HIRÇA

Doç. Dr. Nuriye SEMERCi

Yrd. Doç. Dr. Ayşe Derya IŞIK

Yrd. Doç. Dr. Meliha KÖSE

Yrd. Doç. Dr. Neslihan USTA

Yrd. Doç. Dr. Sevan NART

Yrd. Doç. Dr. Sinem TARHAN

Yrd. Doç. Dr. Süreyya GENÇ

Yabancı Dil Sorumlusu

Yrd. Doç. Dr. Özge GÜN

\section{Yayıma Hazırlık}

Arş. Gör. Arzu ÇEVIK

Arş. Gör. Ömer KEMiksiz

\section{Sekretarya}

Arş. Gör. Hasan Basri KANSIZOĞLU

\section{Teknik Sorumlular}

Arş. Gör. Barış ÇUKURBAŞı

Arş. Gör. Fatma Gizem KARAOĞLAN YILMAZ

\section{İetişim}

Bartın Üniversitesi Eğitim Fakültesi

74100 BARTIN - TÜRKIYE

e-posta: buefad@bartin.edu.tr

Tel: +903782235219

Bartın Üniversitesi Eğitim Fakültesi Dergisi (BÜEFAD), yılda iki kez yayımlanan uluslararası hakemli bir dergidir. Yazıların sorumluluğu, yazarlarına aittir.
Owner

On Behalf of Bartin University Faculty of Education Prof. Firdevs GUNES (Dean)

$\underline{\text { Editor }}$

Asst. Prof. Sedat BALYEMEZ

Field Editors

Assoc. Prof. Cetin SEMERCI

Assoc. Prof. Necati HIRCA

Assoc. Prof. Nuriye SEMERCI

Asst. Prof. Ayse Derya ISIK

Asst. Prof. Meliha KOSE

Asst. Prof. Neslihan USTA

Asst. Prof. Sevan NART

Asst. Prof. Sinem TARHAN

Asst. Prof. Sureyya GENC

Foreign Language Specialist

Asst. Prof. Ozge GUN

Preparing for Publication

RA. Arzu CEVIK

RA. Omer KEMIKSIZ

Secretary

RA. Hasan Basri KANSIZOGLU

$\underline{\text { Technical Assistants }}$

RA. Baris CUKURBASI

RA. Fatma Gizem KARAOGLAN YILMAZ

Contact

Bartin University Faculty of Education 74100 BARTIN - TURKEY

e-mail: buefad@bartin.edu.tr

Tel: +90 3782235219

Bartin University Journal of Faculty of Education (BUJFED) is a international refereed journal that is published two times a year. The responsibility lies with the authors of papers. 


\section{DiZINLENME VE LISTELENME / INDEXING AND LISTING}

Bartın Üniversitesi Eğitim Fakültesi Dergisi, aşağıdaki indeksler tarafından dizinlenmekte ve listelenmektedir. / Bartin University Journal of Faculty of Education is indexed and listed by the following indexes.

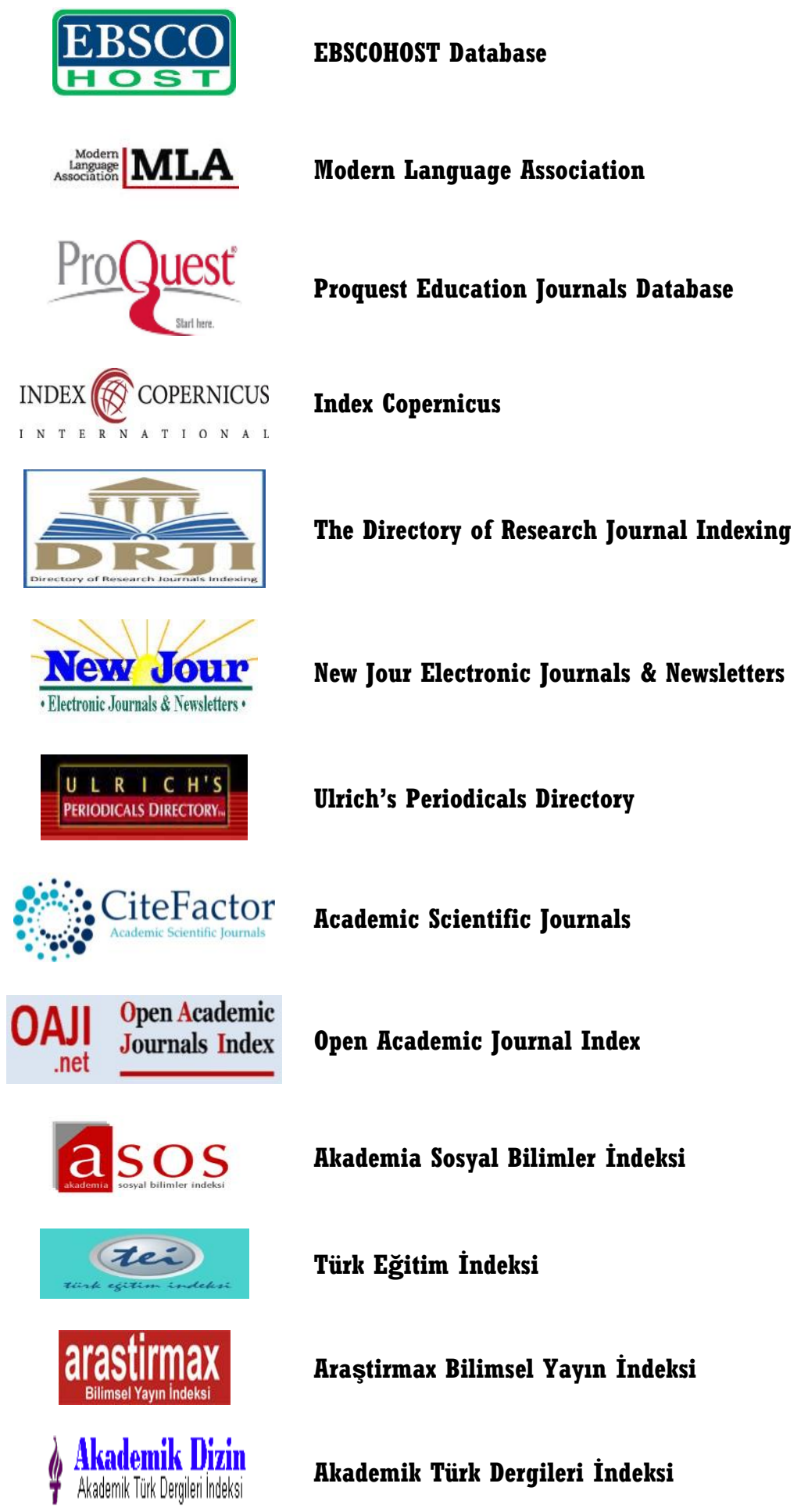


YAYIN DANIŞMA KURULU / EDITORIAL ADVISORYBOARD

Prof. Dr. Ahmet ARIKAN

Prof. Dr. Ahmet GÜNŞEN

Prof. Dr. Ahmet SABAN

Prof. Dr. Aziz KILINÇ

Prof. Dr. Bilgin Ünal iBRET

Prof. Dr. Cemal TOSUN

Prof. Dr. Firdevs GÜNEŞ

Prof. Dr. Firdevs KARAHAN

Prof. Dr. Ahmet KIRKILIÇ

Prof. Dr. Hayati AKYOL

Prof. Dr. Hüseyin ALKAN

Prof. Dr. M. Fatih TAŞAR

Prof. Dr. Mimar TÜRKKAHRAMAN

Prof. Dr. Murat ÖZBAY

Prof. Dr. Ramazan KAPLAN

Prof. Dr. Recai DOĞAN

Prof. Dr. Safure BULUT

Prof. Dr. Sebahattin ARIBAŞ

Prof. Dr. Selahattin TURAN

Prof. Dr. Selma YEL

Prof. Dr. Şefik YAŞAR

Prof. Dr. Yavuz TAŞKESENLIGIL

Doç. Dr. Bahri ATA

Doç. Dr. Çavuş ŞAHIN

Doç. Dr. Çetin SEMERCi

Doç. Dr. Emine KOLAÇ

Doç. Dr. Erol DURAN

Doç. Dr. Eyyüp COŞKUN

Doç. Dr. Kubilay YAZICI

Doç. Dr. Neşe TERTEMiz

Doç. Dr. Nuriye SEMERCi

Doç. Dr. Sabri SIDEKLi

Doç. Dr. Tolga GÜYER
Gazi Üniversitesi

Trakya Üniversitesi

N. Erbakan Üniversitesi

ÇOMÜ

Kastamonu Üniversitesi

Ankara Üniversitesi

Bartın Üniversitesi

Sakarya Üniversitesi

Atatürk Üniversitesi

Gazi Üniversitesi

Dokuz Eylül Üniversitesi

Gazi Üniversitesi

Akdeniz Üniversitesi

Gazi Üniversitesi

Bartın Üniversitesi

Ankara Üniversitesi

ODTÜ

Adıyaman Üniversitesi

Osmangazi Üniversitesi

Gazi Üniversitesi

Anadolu Üniversitesi

Atatürk Üniversitesi

Gazi Üniversitesi

ÇOMÜ

Bartın Üniversitesi

Anadolu Üniversitesi

Uşak Üniversitesi

Mustafa Kemal Üniversitesi

Niğde Üniversitesi

Gazi Üniversitesi

Bartın Üniversitesi

Muğla S. Koçman Üniversitesi

Gazi Üniversitesi 


\section{BU SAYININ HAKEMLERI / REFEREES OFTHIS ISSUE}

Prof. Dr. Ahmet KAÇAR

Prof. Dr. Adnan BAKi

Prof. Dr. Fatma AÇIK

Prof. Dr. Firdevs GÜNEŞ

Prof. Dr. Firdevs KARAHAN

Prof. Dr. Hasan BACANLI

Prof. Dr. Yusuf BUDAK

Doç. Dr. Ali TAŞ

Doç. Dr. Çetin SEMERCi

Doç. Dr. Ebru KILIÇ ÇAKMAK

Doç. Dr. Eyyüp COŞKUN

Doç. Dr. Halit KARATAY

Doç. Dr. Gökhan DEMIRCioĞLU

Doç. Dr. Levent ERASLAN

Doç. Dr. Mehmet Ali ÇAKMAK

Doç. Dr. Mehmet Altan KURNAZ

Doç. Dr. Mustafa ULUSOY

Doç. Dr. Mübin KIYICI

Doç. Dr. Necati HIRÇA

Doç. Dr. Nuriye SEMERCi

Doç. Dr. Orhan AKINOĞLU

Doç. Dr. Özay KARADAĞ

Doç. Dr. Özlem ÇAKMAK

Doç. Dr. Sabri SIDEKLI

Doç. Dr. Yüksel GÖĞEBAKAN

Yrd. Doç. Dr. Abdullah Çağrı BiBBER

Yrd. Doç. Dr. Ahmet YIKMIŞ

Yrd. Doç. Dr. Ahmet AKKAYA

Yrd. Doç. Dr. Ali Rıza ŞEKERCi

Yrd. Doç. Dr. Aslıhan SABAN

Yrd. Doç. Dr. Aynur KOLBURAN GEÇER

Yrd. Doç. Dr. Ayşe Derya IŞIK

Yrd. Doç. Dr. Ayşe GÜLER

Yrd. Doç. Dr. Burcu DUMAN

Yrd. Doç. Dr. Cemal TOSUN

Yrd. Doç. Dr. Çığıl AYKUT

Yrd. Doç. Dr. Devrim AKGÜNDÜZ

Yrd. Doç. Dr. Fulya TOPÇUOĞLU ÜNAL

Yrd. Doç. Dr. Gamze Elif TANINMIŞ

Yrd. Doç. Dr. Güliz AYDIN

Yrd. Doç. Dr. İbrahim GÖKTAŞ

Yrd. Doç. Dr. İlhan YALÇIN
Kastamonu Üniversitesi

Karadeniz Teknik Üniversitesi

Gazi Üniversitesi

Bartın Üniversitesi

Sakarya Üniversitesi

Yıldız Teknik Üniversitesi

Gazi Üniversitesi

Kırıkkale Üniversitesi

Bartın Üniversitesi

Gazi Üniversitesi

Mustafa Kemal Üniversitesi

Abant İzzet Baysal Üniversitesi

Ondokuz Mayıs Üniversitesi

Kırıkkale Üniversitesi

Gazi Üniversitesi

Kastamonu Üniversitesi

Gazi Üniversitesi

Sakarya Üniversitesi

Bartın Üniversitesi

Bartın Üniversitesi

Marmara Üniversitesi

Düzce Üniversitesi

Gazi Üniversitesi

Muğla Sıtkı Koçman Üniversitesi

İnönü Üniversitesi

Kastamonu Üniversitesi

Abant İzzet Baysal Üniversitesi

Adıyaman Üniversitesi

Dumlupınar Üniversitesi

Konya Üniversitesi

Kocaeli Üniversitesi

Bartın Üniversitesi

Kırıkkale Üniversitesi

Bartın Üniversitesi

Bartın Üniversitesi

Gazi Üniversitesi

İstanbul Aydın Üniversitesi

Dumlupınar Üniversitesi

Gazi Üniversitesi

Ordu Üniversitesi

Adnan Menderes Üniversitesi

Ankara Üniversitesi 
Yrd. Doç. Dr. M. Sani ADIGÜZEL

Yrd. Doç. Dr. Mehmet Diyaddin YAŞAR

Yrd. Doç. Dr. Mehmet UMUZDAŞ

Yrd. Doç. Dr. Metin DENIZ

Yrd. Doç. Dr. Murat GENÇ

Yrd. Doç. Dr. Nail iLHAN

Yrd. Doç. Dr. Nalan OKAN AKIN

Yrd. Doç. Dr. Nuray MAMUR

Yrd. Doç. Dr. Özcan KARAASLAN

Yrd. Doç. Dr. Özge GÜN

Yrd. Doç. Dr. Sedat BALYEMEZ

Yrd. Doç. Dr. Semra KIRANLI GÜNGÖR

Yrd. Doç. Dr. Sibel SADI

Yrd. Doç. Dr. Suad SAKALLI GÜMÜŞ

Yrd. Doç. Dr. Sultan Bilge KARA

Yrd. Doç. Dr. Süleyman AVCI

Yrd. Doç. Dr. Şenel ELALDI

Yrd. Doç. Dr. Şeyda GÜL

Yrd. Doç. Dr. Tolga KABACA

Yrd. Doç. Dr. Tuncay Yavuz ÖZDEMiR

Yrd. Doç. Dr. Yakup DOĞAN

Dr. Hayriye Tuğba ÖZTÜRK
İstanbul Aydın Üniversitesi

Kilis 7 Aralık Üniversitesi

Gaziosmanpaşa Üniversitesi

Bartın Üniversitesi

Düzce Üniversitesi

Kilis 7 Aralık Üniversitesi

Niğde Üniversitesi

Pamukkale Üniversitesi

Marmara Üniversitesi

Bartın Üniversitesi

Bartın Üniversitesi

Eskişehir Osmangazi Üniversitesi

Kafkas Üniversitesi

Mustafa Kemal Üniversitesi

Okan Üniversitesi

Marmara Üniversitesi

Cumhuriyet Üniversitesi

Atatürk Üniversitesi

Pamukkale Üniversitesi

FIrat Üniversitesi

Kilis 7 Aralık Üniversitesi

Ankara Üniversitesi 


\section{IÇINDEKILER / CONTENTS}

\section{Prof. Dr. Firdevs GÜNEŞ}

Konuşma Öğretimi Yaklaşım ve Modelleri

Speech Teaching Approaches and Models

doi number: 10.14686/BUEFAD.201416205

\section{Barış ÇUKURBAŞı - Prof. Dr. Aytekin IŞMAN}

Öğretmen Adaylarının Dijital Yerli Özelliklerinin Incelenmesi (Bartın Üniversitesi Örneği)

Examination of Teacher Candidates' Digital Natives Features (Example of Bartın University)

doi number: 10.14686/BUEFAD.201416206

Yrd. Doç. Dr. Süleyman GÖKSOY - Doç. Dr. Engin ASLANARGUN

Denetim Sürecinde Eğitim Denetmenlerinin Davranışları

Behaviours of Supervisors in the Process of Supervision

$55-77$

doi number: 10.14686/BUEFAD.201416207

Arş. Gör. Yunus ÖZYURT - Doç. Dr. Altay EREN

Fen Bilgisi Öğretmen Adaylarının Öğretmenlik Mesleğine ve Kopya Çekmeye Yönelik Tutumlarının Görünümü

Profiles of Pre-Service Science Teachers' Attitudes towards the Teaching Profession and Cheating doi number: 10.14686/BUEFAD.201416208

\section{Yrd. Doç. Dr. Sefa DÜNDAR}

The Investigation of Spatial Skills of Prospective Teachers with Different Cognitive

Bilissel Stilleri Farklı Ogretmen Adaylarının Uzamsal Becerilerinin Incelenmesi

doi number: 10.14686/BUEFAD.201416209

Yrd. Doç. Dr. Abdulkerim KARADENiz

Eleştirel Okuma Özyeterlilik Algısı Ölçeğinin Geçerlilik ve Güvenirlik Çalışması

Critical Reading Self-Efficacy Perception Scale Validity and Reliability Study

doi number: 10.14686/BUEFAD.201416210

Yrd. Doç. Dr. Ayşen KARAMETE - Öğr. Gör. Hüseyin GÜNEŞ

İlköğretim Seçmeli Satranç Dersi Başlangıç Düzeyi Birinci Basamak Bilgisayar Destekli Öğretim Tasarımı

Primary School First Grade Beginner Level Chess Course Computer-Aided Instructional Design

doi number: 10.14686/BUEFAD.201416211

Doç. Dr. Fahri TEMizYÜREK - Arş. Gör. Arzu ÇEVIK

Mustafa Ruhi Şirin'in Çocuk Edebiyatı Sahasındaki Eserlerinin Dil ve Kavram Bağlamında İncelenmesi

Examination of Mustafa Ruhi Sirin's Works in Field of Children's Literature According to Context of Language

Concept

doi number: 10.14686/BUEFAD.201416212

Dr. Gizem KARAOĞLAN YILMAZ - Dr. Ramazan YILMAZ - Arş. Gör. Barış SEZER

Üniversite Öğrencilerinin Güvenli Bilgi ve İletişim Teknolojisi Kullanım Davranışları ve Bilgi Güvenliği Eğitimine Genel Bir Bakış

Secure Information and Communication Technology Usage Behavior of University Students and an Overview

to Information Security Training

$176-199$

doi number: 10.14686/BUEFAD.201416213 


\section{IÇINDEKILER / CONTENTS}

\section{Yrd. Doç. Dr. Erdal TAŞLIDERE}

Kavramsal Değişim Yaklaşımının Doğru Akım Devreleri Konusundaki Kavram Yanılgılarının Giderilmesine Etkisi

Effect of Conceptual Change Instruction on Remedying Misconceptions Concerning Direct Current Circuits doi number: 10.14686/BUEFAD.201416214

\section{Dr. H. Tuğba ÖzTÜRK}

Küreselleşme ve Ağ Toplumları Odağında Bilgi ve Illetişim Teknolojileri ile Eğitim Education with Information and Communication Technologies in the Scope of Globalisation and Network Society doi number: 10.14686/BUEFAD.201416215

Yrd. Doç. Dr. Serkan TiMUR - Şirin YILMAZ - Yrd. Doç. Dr. Betül TiMUR Fen ve Teknoloji Öğretmenleri İle Öğretmen Adaylarının Fen Deneylerinin Amaçlarını Kavramaya Yönelik Tutumlarının İncelenmesi Investigating Science and Technology Teachers' and Pre-Service Teachers' Attitudes towards Understanding the Objectives of Science Experiments doi number: 10.14686/BUEFAD.201416216

\section{Fazilet Eda YILMAZ - Gülşah TOPALOĞLU - Mustafa AKYÜZLÜER}

Grupla Yapılan Müzik Etkinliğinin Otizmli Çocukların Sosyal Becerilerine Etkisinin Betimlenmesi

Description of the Effect of Musical Activity with Group on Social Skills of Children with Autism doi number: 10.14686/BUEFAD.201416217

Yrd. Doç. Dr. Özcan Erkan AKGÜN - Şirin KÜçÜK

Barış ÇUKURBAŞI - İsmail TONBULOĞLU

Sözel veya Görsel Baskın Öğrenme Stilini Belirleme Ölçeği Türkçe Formunun Geçerlik ve Güvenirlik Çalışması

Validity and Reliability Study of the Visual versus Verbal Style of Processing Scale Turkish Form doi number: 10.14686/BUEFAD.201416218

Arş. Gör. Ruhşen ALDEMiR - Doç. Dr. Enver TATAR Teknoloji Destekli Matematik Eğitimi Hakkında Yayınlanan Makalelerinin İncelenmesi An Analysis of Articles on Technology Assisted Mathematics Education doi number: 10.14686/BUEFAD.201416219

İsmail TONBULOĞLU - Prof. Dr. Aytekin IŞMAN

Öğretmenlerin Sosyal Ağları Kullanım Profillerinin İncelenmesi

Exploring Teachers' Social Network Usage

doi number: 10.14686/BUEFAD.201416220

Arş. Gör. Dr. Osman çiMEN - Prof. Dr. Mehmet YILMAZ Dönüşümsel Öğrenme Kuramına Dayalı Çevre Eğitiminin Biyoloji Öğretmen Adaylarının Çevre Sorunlarına Yönelik Algılarına Etkisi The Influence of Transformative Learning Based Environmental Education on Preservice Biology Teachers' Perception of Environmental Problems doi number: 10.14686/BUEFAD.201416221

Doç. Dr. İ. Halil TÜRKER - Yrd. Doç. Dr. Fatih ÖZDEMiR Resim-İş Eğitimi Programları Grafik Ana Sanat Ders İçerikleri ve İşleniş Biçimleri Course Outlines and Teaching Styles at Graphic Design Lessons at Fine Arts Education Departments doi number: 10.14686/BUEFAD.201416222 


\section{IÇINDEKILER / CONTENTS}

\section{Yrd. Doç. Dr. Süreyya GENÇ}

Sanat Eğitiminde Eğitsel Oyunların Önemi

Importance of Educational Games in Arts Education

doi number: 10.14686/BUEFAD.201416223

Doç. Dr. Lale HÜSEYNOVA

Müzik Öğretmenliği Bölümü Öğrencilerinin Keman Çalma Performanslarını Etkileyen Bazı Değişkenler

Some Variables that Affect the Violin - Playing Performance of Students in the Department of Music Teaching doi number: 10.14686/BUEFAD.201416224

\section{Yrd. Doç. Dr. Vafa SAVAŞKAN}

Eğitim Fakültesi Öğrencilerinin Günlük Tutma Alışkanlıklarının Öğrenci Görüşleri Doğrultusunda İncelenmesi

Investigate the Logging Habits of the Faculty of Education Students in Terms of Students' Opinion doi number: 10.14686/BUEFAD.201416225

Arş. Gör. Melehat GEZER - Prof. Dr. İbrahim Fevzi ŞAHIN

Yrd. Doç. Dr. Meral ÖNER SÜNKÜR - Arş. Gör. Elif MERAL

8. Sınıf Türkiye Cumhuriyeti İnkılâp Tarihi ve Atatürkçülük Dersi Öğretim Programı Kazanımlarının Revize Edilmiş Bloom Taksonomisine Göre Değerlendirilmesi

An Evaluation of the Outcomes of the 8th Grade History of Turkish Revolution and Kemalism Lesson According to Revized Bloom's Taxonomy doi number: 10.14686/BUEFAD.201416226

Prof. Dr. Firdevs GÜNEŞ - Doç. Dr. Coşkun ARSLAN - Arş. Gör. Ayşe ELiÜşÜK Atılganlık Eğitiminin Üniversite Öğrencilerinin Kişiler Arası Problem Çözme, Algılanan Sosyal Destek ve Atılganlık Düzeyleri Üzerine Etkisi 


\title{
Dönüşümsel Öğrenme Kuramına Dayalı Çevre Eğitiminin Biyoloji Öğretmen Adaylarının Çevre Sorunlarına Yönelik Algılarına Etkisi
}

\author{
Arş. Gör. Dr. Osman çiMEN \\ Gazi Üniversitesi \\ Gazi Eğitim Fakültesi \\ osman.cimen@gmail.com
}

\author{
Prof. Dr. Mehmet YILMAZ \\ Gazi Üniversitesi \\ Gazi Eğitim Fakültesi \\ myilmaz@gazi.edu.tr
}

\begin{abstract}
Özet: Bu çalışmanın amacı dönüşümsel öğrenme kuramına dayalı çevre eğitiminin biyoloji öğretmen adaylarının çevre sorunlarına yönelik algılarına etkisini incelemektir. Araştırma modeli nicel ve nitel araştırma yöntemlerinin birlikte kullanıldığı karma yöntem olarak tasarlanmıştır. Araştırma uygulamaları Gazi Üniversitesi Biyoloji Eğitimi Anabilim Dalında öğrenim gören 28 biyoloji öğretmen adayı ile 14 hafta sürede gerçekleştirilmiştir. Araştırmada nicel verilerin toplanmasında çevre sorunları bilgisi testi, çevre sorunları tutum ölçeği, çevreye duyarlı davranış ölçeği ve çevreye yönelik inanç ölçeği; nitel verilerin toplanmasında yarı yapılandırımış görüşme formu uygulanmıştır. Nicel veriler SPSS 18 paket programı ile nitel veriler ise içerik analizi yöntemi ile analiz edilmiş, frekans ve yüzde olarak ifade edilmiştir. Araştırma sonunda dönüşümsel öğrenme modelinin uygulandığı deney grubunun çevre sorunları bilgisi, çevre sorunlarına yönelik tutum, çevreye yönelik inanç ve çevreye duyarlı davranış düzeylerinin, geleneksel yöntemin uygulandığı kontrol grubuna göre anlamlı olarak farklılaştığı belirlenmiştir.
\end{abstract}

Anahtar Kelimeler: Dönüşümsel öğrenme, Çevre eğitimi, Çevreye yönelik tutum, Çevre sorunları bilgisi, Çevreye duyarlı davranış

\section{The Influence of Transformative Learning Based Environmental Education on Preservice Biology Teachers' Perception of Environmental Problems}

\begin{abstract}
The aim of the present study is to investigate the effect of transformative learning based environmental education on preservice biology teachers' perceptions of environmental problems. In the research model, the mixed model comprising quantitative and qualitative research methods was employed. The quantitative dimension included the experimental method while the qualitative method included a case study. The administration of the instruments took place with the participation of 28 preservice biology teachers studying at Gazi University Biology Education department for 14 weeks. Environmental problems knowledge test, environmental problems attitudes test, environmental sensitivity test and environmental beliefs test were used in the collection of quantitative data, while semi-structured interview form was used in the collection of qualitative data. Quantitative data were analyzed by means of SPSS 18 software, whereas qualitative data were analyzed by means of content analysis and expressed in frequency and percentage. The results revealed that the experimental group which was exposed to the transformative learning model significantly differed from the control group which was exposed to the traditional method in terms of environmental problems knowledge, attitudes to environmental problems, environmental beliefs, and environmentally sensitive behaviors.
\end{abstract}

Key Words: Transformative learning, Environmental education, Environmental attitude, Knowledge of environmental problems, Environmentally-sensitive behavior

\footnotetext{
${ }^{*}$ Bu çalışma doktora tezinden üretilmiştir.
} 


\section{GiRiş}

Doğal kaynakların hızla tüketildiği, küresel ısınmanın etkisinin arttığı, iklimlerin değiştiği günümüzde, önceleri yerel ve küresel olarak adlandırılan çevre sorunları şu an ülkelerin sınırlarını aşmış, tüm dünyanın ortak sorunu olmuştur (Aksay, Ketenoğlu ve Kurt, 2005).

Her gün yeni bir modeli çıkan arabalar, akıllı cep telefonları, yeni model bilgisayarlar insanlarda tüketim cazibesi oluşturmaktadır. Birçok insan içinde bulunduğumuz dönemde yeni bir tüketim ürününün etkisinde kalıp alışveriş çılgınlığına katılmaktadır. Evlerde birden fazla televizyon, bilgisayar, buzdolabı ve kullanılmayan ayakkabı çiftleri bilinçsiz tüketim ürünlerinden sadece bazılarıdır. Her yapılan tüketimin bir üretim boyutunun olduğu başka bir ifadeyle doğa üzerine etkisinin bulunduğu birçok insan tarafından göz ardı edilmektedir.

Yaşam standartlarının giderek yükselmesi ve dünya nüfusundaki hızlı artış doğal kaynakların aşırı kullanımına sebep olmaktadır. Artan nüfusun beslenme ve barınma gibi ihtiyaçları, doğal kaynak kullanımını hızlandırarak ciddi çevre sorunlarını beraberinde getirmiştir. Günümüzde bu sorunlar tüm dünyayı tehdit eder hale gelmiştir (Oweini ve Houri, 2006).

Sanayi devrimi ve bunun sonucunda bilim ve teknoloji alanlarında yaşanan gelişmeler insan-doğa dengesini insan lehine bozarak, insana doğaya müdahale imkanı vermiş ve bunun sonucunda da ekolojik denge bozulmuştur. Ekolojik dengenin bozulmasıyla hızla toprak kaybı, canlı türlerinin yok olması, çölleşme, asit yağmurları, açlık, yoksulluk, radyoaktif kirlenme gibi çevre sorunları artmıştır. Bu sorunların insan yaşamını tehdit eder boyutlara ulaşması sebebiyle insanlar çözüm önerileri aramaya başlamışlardır (Erol ve Gezer, 2006).

Çevre ve insan ilişkisi incelendiğinde bu etkileşimin insanın doğada var olduğu günden bu güne kadar devam ettiği görülmektedir. Giderek artan nüfus, teknolojide meydana gelen gelişmeler ve toplumların değişen yaşam tarzı ile alışkanlıklarının yol açtığı çevre sorunları, doğal kaynaklarda azalma ve bozulmalara neden olmuş özellikle son yarım yüzyılda tüm yaşam sistemlerini tehdit altına sokmuştur (Deniş ve Genç, 2007).

Çevrenin geldiği bu noktada çevre sorunlarının olumsuz etkilerinin ortadan kaldırıması için çevre eğitimine önemli görevler düşmektedir. Çevre eğitimi çevre ile ilgili olaylara yönelik farkındalığın artmasını ve çevre sorunlarının çözümü için gerekli davranışların kazanıımasını sağlamaktadır (Milton, Cleveland ve Bennett-Gates, 1995). Çevre eğitiminde kullanılan geleneksel yaklaşımların çevre sorunlarının giderilmesinde başarılı olmadığı görülmektedir. Son 
yıllarda çevre eğitiminde yeni yaklaşımlar ele alınmakta bu yeni yaklaşımlardan birisi de dönüşümsel öğrenme kuramıdır.

Dönüşümsel öğrenme kuramı ilk kez Mezirow tarafından 1978 yılında ortaya konulan yetişkin öğrenmesi ile ilgili bir yaklaşımdır. Dönüşümsel öğrenme; insanların düşünce yapılarının ve bu yapılarla bağlantılı olan duygu, düşünce, inanç ve bilginin öğrenme sürecinde değişerek yeni yaklaşımlara dönüşmesidir (Mezirow ve Associates, 2000). O'Sullivan (1999) dönüşümsel öğrenmeyi; derinleştirilmiş deneyimlerin gerçekleştiği, yapısal değişikliklerin meydana geldiği; duygu, düşünce ve davranış değişikliklerinin artarak yeni bakış açılarının oluştuğu süreç olarak tanımlamıştır.

Dönüşümsel öğrenme kuramının merkezinde insanların kendilerini eleştirel bir şekilde araştırması, deneyimlerini değerlendirmesi, bu deneyimleri yorumlayarak yeniden adlandırma süreçleri yer alır. Dönüşüm sürecinde yapılan çözümlemeler ve öz değerlendirmeler, eylemlere yön veren deneyimlerin anlamlandırmasını sağlar. Anlamlandırma ya da anlam oluşturma yetişkin öğrenmesinin önemli bir kavramıdır. Bu sosyal süreçte yapılan çözümlemeler ve öz eleşitiriler eylemlerin oluşmasını sağlayan deneyimleri anlamlandırır (Mezirow, 1994).

Dönüşümsel öğrenme süreci 10 aşamadan oluşmaktadır. Bunlar;

1. İilem oluşturma

2. Suçluluk ve utanç duyguları ile kendini değerlendirme (Kendini ilgili konu ile ilgili olarak inceleme, örneğin çevre sorunları konusunda yeterli bilgiye sahip mi, bu konudaki endişeleri, korkuları var mı? gibi sorularla bireyin kendini sorgulaması sağlanır.)

3. Bireylerin sahip olduğun varsayımların çok yönlü olarak değerlendirilmesi

4. Dönüşüm sürecinin farkında olma

5. Yeni rol, davranış, ilişkilerle ile ilgili düşüncelerin paylaşımı

6. Yapılması gerekenlerle ile ilgili bir yol haritası, bir plan oluşturulması

7. Planların uygulanması için bilgi ve beceri kazanımı

8. Yeni rollerin denenmesi

9. Bireyler arası yeni roller, özgüven ilişkilerinin kurulması

10. Bireylerin sahip olduğu yeni perspektifin yaşama katılmasıdır (Mezirow ve Associates, 2000).

Dönüşüm süreci ikilem oluşturma ile başlar. íkilem oluşması süreci kendini irdeleme ve varsayımların eleştirel olarak değerlendirilmesi süreci ile devam eder. Katılımcl; ikilem oluşturma sürecinin, dönüşümün bir bölümü olduğunu bilmelidir. Bu noktada katılımcı bilinçli 
bir şekilde yeni roller, yeni ilişkiler ve yeni eylemler araştııır. Katılımcı bu eylemleri geçilebilmesi için yeni bir eğitim kursuna başlamalıdır. Bu kursta yeni roller ve yeni planlar için gerekli olan bilgi ve beceri kazanılır. Yeni roller ve ilişkilerle ilgili deneyimler öz güven ve yeterlilik oluşmasını sağlar. Böylelikle katıımcı edindiği yeni roller ve ilişkileri yaşamına katar. Eğer dönüşüm doğru bir şekilde gerçekleşmişse kazanılan bu süreç yeni perspektif olarak ifade edilir (McWhinney ve Markos, 2003).

Dönüşümsel öğrenme kuramının temel özelliği insanların bütün özellikleri ile değişmesini sağlayarak olaylara, hayata farklı bakış açıları kazanmalarını sağlamaktır. Çevrenin bugün geldiği olumsuzluklardan, çevre sorunlarından kurtulması insanların çevreye karşı mevcut bakış açılarının; tutum, bilgi, davranış, inanç gibi özelliklerinin değiştirilmesi ile gerçekleşebilir.

Pek çok bilim insanına göre insanoğlunun sürdürülebilir davranış göstermemesinin sebebi, çevre ile ilgili yetersiz bilgiye sahip olma ve davranışların sonuçlarını düşünmemeleridir (Williamson ve Lynch, 2001). Günümüzde çevre bilgisinin çevre davranışlarının yordanmasında etkisi tartışılmaktadır. Çevre eğitimi ile ilgili araştırmaların bir bölümünde çevre bilgisinin, farkındalıklarının artması ve çevreye duyarlı davranışları üzerine tek başına anlamlı bir etkiye sahip olmadığı bildirilmektedir (Ramsey ve Rickson, 1976; Hungerford ve Volk, 1990). Çevre bilgisinin yanı sıra pek çok faktör çevreye duyarlı davranışları etkilemektedir (Ajzen, 1991; Hungerford ve Volk, 1990).

Illgili literatürde farklı çevre eğitimi uygulamalarının çevreye ilişkin tutum üzerine etkisinin araştırıldığı birçok çalışma bulunmaktadır. Dettman-Easler ve Pease (1999)'in yaptıkları çalışmada sınıf dışı öğrenme etkinliklerinin öğrencilerin çevreye yönelik tutumlarına etkisini araştırmışlardır. Smith-Sebasto ve Semrau (2004), yetişkinlerle yaptıkları çalışmada çevre programlarının etkililiğini araştırmışlardır. Keleş, Uzun ve Varnacı Uzun (2010), öğretmen adaylarının çevreye yönelik düşünce, davranış ve tutumları üzerine doğa eğitimin etkisini araştırmıştır.

Literatürde birçok araştırmada çevre eğitimi programlarının çevreye duyarlı davranışları olumlu olarak etkilediğini göstermektedir. Jordan, Hungerford ve Tomera (1986) yaptıkları araştırmada çevre sorunlarına yönelik eylem planlarının öğrencilerin çevreye duyarlı davranışını anlamlı olarak arttığını belirlemişlerdir. Dresner ve Gill (1994) doğa kampları eğitiminin öğrencilerin çevreye duyarlı davranışlara etkisini incelemişlerdir. Çalışma sonunda 
öğrenci aileleri ile yapılan görüşmelerde aileler çocuklarının çevreye duyarlı davranışlarının arttığını ifade etmişlerdir.

\subsection{Amaç}

Çevrenin daha iyi bir duruma gelebilmesi için toplumların değişmesine, yeni bir çevre anlayışına oluşmasına ihtiyaç duyulmaktadır. Bu değişimin temel öğesi de insan olmalıdır. Böylelikle toplumun tüm kesimlerinde farkındalık oluşturularak bireysel ve toplumsal değişim sağlanabilecektir. Bu doğrultuda bireylerin bütün özellikleri ile değişimini temel alan dönüşümsel öğrenme kuramına dayalı çevre eğitimine ihtiyaç duyulmuştur. Böylece bu çalışmanın problem cümlesi "Dönüşümsel öğrenme kuramına dayalı çevre eğitiminin biyoloji öğretmen adaylarının algılarına etkisi nasıldır?" şeklinde belirlenmiştir. Bu genel amaç doğrultusunda araştırmada şu sorulara yanıt aranmıştır.

1. Uygulama öncesinde kontrol ve deney grubunun; çevre sorunları bilgisi, çevre sorunlarına yönelik tutum, çevreye yönelik inanç ve çevreye duyarlı davranış puanları arasında anlamlı farklılık var mıdır?

2. Uygulama sonunda kontrol ve deney grubunun çevre sorunları bilgisi, çevre sorunlarına yönelik tutum, çevreye yönelik inanç ve çevreye duyarlı davranış son test puanları arasında anlamlı farklılık var mıdır?

3. Dönüşümsel çevre eğitimi uygulamaları sonunda deney grubunun çevre sorunlarına yönelik bilgi, tutum, inanç ve davranışlarında meydana gelen değişiklikler nelerdir?

\section{YÖNTEM}

Bu çalışmada nicel ve nitel araştırma yöntemleri birlikte kullanılmıştır. Her iki yöntemin birlikte kullanıldığı araştırma desenleri karma yöntem olarak ifade edilmektedir (Creswell, 2003). Karma yöntem araştırması, araştırmacının tek bir çalışma içerisinde nicel ve nitel araştırma tekniklerini, yöntemlerini, yaklaşımlarını, kavramlarını veya dilini karıştırdığı ya da birleştirdiği araştırma sınıfı olarak tanımlanabilir (Johnson ve Onwuegbuzie, 2004). Başka bir ifadeyle karma yöntem araştırmacıların nitel ve nicel verileri kullanarak araştırma soru veya sorularına cevap aranmasıdır (Hesse-Biber ve Leavy, 2004). araştırmada kullanılan desene ilişkin bilgiler Tablo 1 'de verilmiştir. 
Tablo 1: Araştırma Deseni

\begin{tabular}{|c|c|c|c|}
\hline Grup & Ön Test & Öğretim Süreci & Son Test \\
\hline & ÇSBT, ÇSTÖ, ÇYiÖ, ÇDDÖ & & ÇSBT, ÇSTÖ, ÇYiÖ, ÇDDÖ \\
\hline Kontrol Grubu & & $\begin{array}{l}\text { Geleneksel } \\
\text { Yöntem }\end{array}$ & \\
\hline \multicolumn{4}{|l|}{ Deney Grubu } \\
\hline & ÇSBT, ÇSTÖ, ÇYiÖ, ÇDDÖ & $\begin{array}{l}\text { Dönüşümsel } \\
\text { Öğrenme }\end{array}$ & ÇSBT, ÇSTÖ, ÇYiÖ, ÇDDÖ \\
\hline & Yarı Yapılandırılmış Görüşme & $\begin{array}{l}\text { Kuramına Dayalı } \\
\text { Cevre Eğitimi }\end{array}$ & Yarı Yapılandırılmış Görüşme \\
\hline
\end{tabular}

(ÇSBT: Çevre Sorunları Bilgisi Testi, ÇSTÖ: Çevre Sorunları Tutum Ölçeği; çYiö: Çevreye Yönelik İnanç Ölçeği, ÇDDÖ: Çevreye Duyarlı Davranış Ölçeği)

Araştırmada dönüşümsel öğrenme kuramına dayalı çevre eğitiminin biyoloji öğretmen adaylarında çevre sorunları bilgisi, tutum, çevreye yönelik inanç ve çevre duyarlı davranışlarına etkisi araştırılmıştır. Bu kapsamda çalışmada karma yöntem araştırma deseni olarak belirlenmiştir. Araştırmada ön test son test kontrol gruplu deneysel desen ile durum çalışması birlikte kullanılmıştır. Kontrol grubuna düz anlatımın kullanıldığı geleneksel öğrenme yöntemi, deney grubuna ise dönüşümsel öğrenme kuramına dayalı çevre eğitimi uygulanmıştır. Araştırmada nicel ve nitel ölçme araçları birlikte uygulanmıştır ve sonuçları araştırmanın sonucunda bir araya getirilmiştir.

\subsection{Evren ve Örneklem}

Çalışmanın evrenini Ankara'da Hacettepe Üniversitesi ve Gazi Üniversitesi Orta Öğretim Biyoloji Öğretmenliği programları 1. sınıfta kayıtlı olan öğretmen adayları oluşturmaktadır. Araştırmanın örneklemini ise Gazi Üniversitesi Gazi Eğitim Fakültesi Biyoloji Eğitimi Anabilim Dalında 2012-2013 eğitim yılı bahar döneminde 1. sınıfta kayıtlı 28 biyoloji öğretmen adayından oluşmaktadır. Öğretmen adaylarından 14'ü kontrol grubunda, diğer 14'ü ise deney grubunda yer almaktadır. Çalışma grubuna ait betimsel bilgiler Tablo 2'de verilmiştir. 
Tablo 2: Çalışma Grubuna Ait Betimsel Bilgiler

\begin{tabular}{lll}
\hline Değişken & Frekans (f) & Yüzde (\%) \\
\hline Cinsiyet & 25 & $\% 89$ \\
Kız & 3 & $\% 11$ \\
Erkek & 28 & $\% 100$ \\
Toplam & & $\%$ \\
Yaş & 12 & $\% 43$ \\
17 & 14 & $\% 50$ \\
18 & 2 & $\% 7$ \\
19 & 28 & $\% 100$ \\
Toplam & & $\% 100$ \\
Çevre Dernek Üyeliği & & \\
Üye & 5 & $\% 11 \%$ \\
Üye Değil & 23 & $\% 18$ \\
Toplam & 28 & \\
\hline
\end{tabular}

Tablo 2 incelendiğinde çalışma grubunun \%89'nun kız, \%11'nin erkek olduğu; \%43'ünün 17, \%50'sinin 18 ve \% 7'sinin 19 yaşında olduğu; \%18'nin çevre dernek üyesi olduğu, \%82'sinin çevre dernek üyesi olmadığı görülmektedir.

\subsection{Veri Toplama Araçları}

Çalışmada veri toplama araçları olarak Çevre Sorunları Bilgisi Testi (ÇSBT), Çevre Sorunlarına Yönelik Tutum Ölçeği (ÇSTÖ), Çevreye Yönelik İnanç Ölçeği (ÇYiö), Çevreye Duyarlı Davranış Ölçeği (ÇDDÖ), yarı yapılandırılmış görüşme formları kullanılmıştır.

Çevre sorunları bilgisi testi araştırmacılar tarafından geliştirilmiş olup ölçekte 25 madde yer almaktadır. ÇSBT'nin geliştirilme sürecinde önce konuyla ilgili literatür incelenmiş, çevre sorunları ile ilgili temalar oluşturulmuştur. Her bir tema için literatürde yer alan sorulardan ve araştırmacı tarafından hazırlanan sorularla madde havuzu oluşturulmuştur. Bir alan uzmanı ile birlikte madde havuzundan sorular seçilmiş ve taslak ÇSBT oluşturulmuştur. Taslak ölçekte 32 
madde yer almaktadır. Taslak ÇSBT alan, alan eğitimi ve Türkçe uzmanları tarafından incelenmiş, uzman görüşleri doğrultusunda gerekli düzenlemeler yapılmıştır. Taslak ÇSBT ölçeği 30 biyoloji öğretmen adayından oluşan bir gruba uygulanmış, öğretmen adaylarının anlaşılabilirlik, görünüş gibi özelliklere göre ölçekle ilgili görüşleri istenmiştir. Taslak ÇSBT ölçeği çevre dersi almış biyoloji, fen bilgisi ve coğrafya öğretmen adaylarından oluşan 150 kişiden oluşan bir gruba uygulanarak ölçeğin güvenirlik çalışmaları yapılmıştır. Madde analizleri sonucunda madde ayırt edicilik indeksi güvenirliği .30'un altında olan 4 madde ölçekten çıkartılmış ve nihai ÇSBT geliştirilmiştir. Nihai ÇSBT ölçeğinin KR 20 değeri ,74 olarak belirlenmiştir.

Çalışma grubunda yer alan biyoloji öğretmen adaylarının çevre sorunlarına yönelik tutumlarını belirlemek amacıyla Çevre Sorunlarına Yönelik Tutum Ölçeği kullanılmıştır. Ölçek Şama (2003) tarafından geliştirilmiş olup, ölçekte 21 madde yer almaktadır. ÇSTÖ 5'li likert tipte olup, ölçekte yer alan seçenekler "kesinlikle katılmıyorum", "katılmıyorum", "kararsızım", "katılıyorum" ve "kesinlikle katılıyorum" şeklinde verilmiştir. ÇSTÖ'de yer alan maddelerden 10'u olumsuz 11'i ise olumludur. ÇSTÖ'nün Cronbach Alpha güvenirlik katsayısı, 77 olup ölçek tek boyuttan oluşmaktadır.

Çevreye yönelik inanç ölçeği olarak "Yeni Ekolojik Paradigma" ölçeği kullanılmıştır. Ekolojik Paradigma ölçek Dunlap ve diğerleri (2000) tarafından geliştirilmiş; Sam, Sam ve Öngen (2010) tarafından Türkçe'ye uyarlanıp, geçerlilik ve güvenirlik çalışmaları yapılmıştır. Ölçeğin Cronbach Alpha güvenirlik katsayısı, 53 olarak verilmiştir. Ölçekte yer alan maddeler çevre merkezci yaklaşımları ölçen sorular ve insan merkezci yaklaşımları ölçen sorular olmak üzere iki alt soru grubundan oluşmaktadır. Ölçek 5'li likert tipte olup, 14 madde bulunmaktadır. Ölçekte yer alan seçenekler "Kesinlikle katılmıyorum", "Katılmıyorum", "Kararsızım", "Katılıyorum" ve "Kesinlikle Katılıyorum" şeklinde verilmiştir.

Çalışma grubunda yer alan biyoloji öğretmen adaylarının çevre duyarlı davranışlarını tespit emek amacıyla araştırmacı tarafından geliştirilen Çevreye Duyarlı Davranış Ölçeği (ÇDDÖ) kullanılmıştır. Ölçek geliştirme sürecinde öncelikle ilgili literatür incelenmiştir. Öğretmen adaylarından oluşan bir gruba yaptıkları çevre duyarlı davranışlar açık uçlu sorular ile sorulmuştur. Açık uçlu soruların analiz edilmesi ile davranışla ilgili maddeler oluşturulmuştur. Literatürde yer alan maddeler birleştirilerek madde havuzu oluşturulmuştur. Madde havuzundan uzman görüşü doğrultusunda taslak ölçek geliştirilmiştir. Geçerlilik ve güvenirlik analizleri sonucunda ölçeğin Kaiser-Meyer-Olkin (KMO) katsayısı ,789 ve Barlett Sphericity testi 
anlamlılık düzeyi 0,00 olarak belirlenmiştir. Yapılan değerlendirmeler sonucunda ölçeğin üç faktörlü olduğu, bu üç faktörün ölçeğe ilişkin açıkladıkları toplam varyansın \%61,1 olduğu tespit edilmiştir. ÇDDÖ'nün güvenirlik katsayısı ,79 olarak ortaya çıkmıştır. Ölçekte yer alan ifadelerin içerikleri ve ilgili literatür taraması sonucunda ölçek faktörleri çevre ilgi, çevre koruma ve geri kazanım olarak isimlendirilmiştir.

Uygulama sonunda deney grubundan 7 öğrenci ile yarı yapılandırılmış görüşmeler yapılmıştır. Görüşme formunda çevre sorunları bilgisi, tutum, inanç ve davranışla ilgili değişikliklerin ortaya çıkartılmasına yönelik maddeler yer almaktadır.

\subsection{Deneysel İşlem}

Uygulamalardan önce araştırmada kullanılacak etkinliklerin işlevselliğinin ve uygulama sürecinde karşılaşılabilecek sorunların belirlenebilmesi amacıyla biyoloji öğretmenliği 2. sınıfta öğrenim gören 20 öğrenci ile 2012-2013 öğretim yılı güz döneminde pilot çalışma yapılmıştır. Uygulama sürecinde etkinlikler ile ilgili biyoloji öğretmen adaylarının görüşleri alınmış, gerekli düzenlemeler yapılmıştır.

Asıl uygulama ise; 14 hafta süre ile kontrol grubuna geleneksel yönteme dayalı çevre eğitimi uygulanmış, deney grubuna ise dönüşümsel öğrenme kuramına dayalı çevre eğitimi verilmiştir. Dönüşümsel öğrenme kuramı kapsamında biyografi yazma ve okuma, öz değerlendirme, doğa gezisi, geri kazanım merkezi gezisi, probleme dayalı etkinlikler, senaryo etkinliği, oyun etkinliği, proje ve sergi metafor, konu sunumu, çalışma yaprakları etkinlikleri gerçekleştirilmiştir. Biyografi yazma ve metafor etkinlikleri ile biyoloji öğretmen adayları çevre sorunları konusunda mevcut varsayımlarını çok yönlü olarak yansıtmışlardır. Biyografi okuma etkinliği ile birbirlerinin varsayımlarını görmüş, paylaşımda bulunmuşlardır. Öz değerlendirme etkinlikleri biyoloji öğretmen adaylarının kendilerini eleştirel olarak incelemelerini sağlamıştır. Probleme dayalı etkinlikler ve senaryo etkinlikleri çevre sorunları konusunda farklı bakış açıları geliştirmişlerdir. Geri kazanım merkezi gezisi, doğa yürüyüşü etkinlikleri çevre ile ilgili farkındalık geliştirmelerinde etkili olmuştur. Konu sunumu, çalışma yaprakları çevre sorunları ile ilgili bilgi birikiminin değişimi gerçekleştirmiş; proje ve sergi etkinliği biyoloji öğretmen adaylarında gerçekleşen dönüşümü uygulamaya geçirmiştir.

\subsection{Verilerin Analizi}

Araştırmada ulaşılan veriler nitel ve nicel verilerden oluşmaktadır. Her bir gruptaki veri sayısının 30'dan az olduğu durumlarda parametrik olmayan testler kullanılmaktadır. 
(Büyüköztürk, 2002; Yılmaz ve Yılmaz, 2005). Bu nedenle nicel verilerin analizinde SPSS 18 paket programı kullanılmış ve veriler Mann Whitney U-Testi ve Wilcoxon İşaretli Sıralar Testi kullanılarak değerlendirilmiştir. Nitel veriler ise NVIVO 9 programı ile içerik analiz yapılarak incelenmiştir.

\section{BULGULAR}

Araştırmanın birinci alt problemi "Uygulama öncesinde kontrol ve deney grubunun; çevre sorunları bilgisi çevre sorunlarına yönelik tutum, çevreye yönelik inanç ve çevreye duyarlı davranış puanları arasında anlamlı farklıık var mıdır?" şeklinde belirlenmiştir. Birinci alt probleme ait bulgular aşağıda sunulmuştur.

Tablo 3:Biyoloji Öğretmen Adaylarının ÇSBT, ÇSTÖ, çYiö ve ÇDDö Puanları Mann Whitney U Testi Sonuçları

\begin{tabular}{ccccccc}
\hline Değişken & Grup & N & $\begin{array}{c}\text { Sıra } \\
\text { Ortalaması }\end{array}$ & Sıra Toplamı & U & p \\
\hline \multirow{2}{*}{ Bilgi } & Deney & 14 & 15,43 & 216,00 & 85,000 & 0,570 \\
& Kontrol & 14 & 13,57 & 190,00 & & \\
& Deney & 14 & 14,79 & 207,00 & 94,000 & 0,852 \\
Tutum & Kontrol & 14 & 14,21 & 199,00 & & \\
& Deney & 14 & 14,00 & 196,00 & 91,000 & 0,769 \\
Innanç & Kontrol & 14 & 15,00 & 210,00 & & \\
& Deney & 14 & 14,75 & 206,50 & 94,500 & 0,869 \\
Davranıs & Kontrol & 14 & 14,25 & 199,50 & & \\
\hline
\end{tabular}

Tablo 3'te Mann Whitney U testi sonuçlarına göre deney ve kontrol grubunun ön test bilgi puanları arasında anlamlı bir farklılık olmadığı anlaşılmaktadır $(U=85,000 ; p>0,05)$. Bu bulgu deney ve kontrol grubunun uygulama öncesinde bilgi değişkenine göre birbirine denk olduklarını göstermektedir.

Tutumla ilgili bulgular incelendiğinde deney grubunun sıra ortalaması 14,79; kontrol grubunun sıra ortalaması 14,21 olarak bulunmuştur. Deney ve kontrol grubunun puanları arasındaki farklılığın istatistiksel açıdan önemli olmadığı saptanmıştır $(U=94,00 ; p>0.05)$. Bu 
bulguya bağlı olarak deneysel işlem öncesinde grupların tutum yönünden birbirine denk olduğu söylenebilir.

İnanç ile ilgili bululara göre; deney grubunun sıra ortalaması 14,00; kontrol grubunun sıra ortalaması 15,00'tir. Deney ve kontrol grubunun puanları arasındaki farkın istatistiksel açıdan önemli olmadığı saptanmıştır $(U=91,00 ; p>0,05)$. Bu bulguya göre çevreye yönelik inanç yönünden gruplar arasında denkliğinin var olduğu söylenebilir.

Deney grubunun davranış puanları sıra ortalaması 14,75; kontrol grubunun davranış sıra ortalaması 14,25 'tir. Deney ve kontrol grubunun puanları arasındaki farklılığın istatistiksel olarak anlamlı olmadığı belirlenmiştir $(U=94,500 ; p>0,05)$. Bu bulgu deneysel işlem öncesinde grupların davranış yönünden birbirine denk olduklarını göstermektedir.

Araştırmanın ikinci alt problemi uygulamalardan sonra kontrol ve deney grubunun çevre sorunları bilgisi, çevre sorunlarına yönelik tutum, çevreye yönelik inanç ve çevreye duyarlı davranış son test puanları arasında anlamlı farklılık var mıdır?" şeklinde belirlenmiştir. Tablo 4 'te ikinci alt probleme ait bulgulara yer verilmiştir.

Tablo 4: Deney ve Kontrol Grubunun ÇSBT, ÇSTÖ, çYiö ve çDDö Son Test Puanları Mann Whitney U Testi Sonuçları

\begin{tabular}{|c|c|c|c|c|c|c|c|}
\hline Değişken & Grup & $\mathbf{N}$ & $\begin{array}{c}\text { Sıra } \\
\text { Ortalaması }\end{array}$ & Sira Toplamı & U & p & Eta Kare \\
\hline \multirow{3}{*}{ Bilgi } & Deney & 14 & 19,57 & 274,00 & 27,00 & $0,00^{*}$ & 0,386 \\
\hline & & & & & & & \\
\hline & Kontrol & 14 & 9,43 & 132,00 & & & \\
\hline \multirow{3}{*}{ Tutum } & Deney & 14 & 18,71 & 262,00 & 39,000 & $0,00 *$ & 0,285 \\
\hline & & & & & & & \\
\hline & Kontrol & 14 & 10,29 & 144,00 & & & \\
\hline \multirow{2}{*}{ İnanç } & Deney & 14 & 17,79 & 249,00 & 52,000 & $0,04^{*}$ & 0,216 \\
\hline & Kontrol & 14 & 11,21 & 157,00 & & & \\
\hline \multirow{3}{*}{ Davranış } & Deney & 14 & 18,75 & 262,50 & 38,500 & $0,00 *$ & 0,183 \\
\hline & & & & & & & \\
\hline & Kontrol & 14 & 11,04 & 143,50 & & & \\
\hline
\end{tabular}

Tablo 4'e göre deney grubunun çevre sorunları bilgisi son test puanları sıra ortalaması 19,57; kontrol grubunun sıra ortalaması 9,43'tür. Mann-Whitney U Testi sonucu dikkate 
alındığında deney ve kontrol grubunun çevre sorunları bilgisi son test puanları arasında anlamlı farklılık olduğu görülmektedir $(U=27,00 ; p<0,05)$. Bu farklılık deney grubu lehine ve istatistiksel olarak anlamlıdır. Eta Kare analizi sonucunda, deney grubundaki değişimin kontrol grubundaki değişimden istatistiksel olarak anlamlı miktarda daha fazla olduğu anlaşılmaktadır. Deneysel işlem ÇSBT'deki değişimin \%38,6'sını açıklamaktadır. Bu bulgu çevre sorunları bilgisi üzerine dönüşümsel öğrenme kuramına dayalı çevre eğitiminin geleneksel yönteme göre daha etkili olduğu şeklinde vurgulanabilir. Başka bir ifadeyle dönüşümsel öğrenme kuramına dayalı çevre eğitiminin geleneksel yönteme göre daha etkili olduğuna işaret etmektedir.

Tablo 4'te deney grubunun ÇSTÖ sıra ortalamasının 18,71; kontrol grubunun ÇSTÖ sıra ortalamasının 10,29 olduğu görülmektedir. Mann Whitney U Testi sonucunda deney ve kontrol grubunun son test puanları arasındaki farkın deney grubu lehine anlamlı olduğu saptanmıştır $(U=39,00 ; p<0,05)$. Eta Kare sonucunda; deney grubundaki değişimin, istatistiksel olarak kontrol grubundaki değişimden daha fazla olduğu görülmektedir. Bir başka deyişle deneysel işlem, çevreye yönelik tutumu arttırmada etkili olmuştur. Deneysel işlemin, deney grubunun çevre sorunlarına yönelik tutumdaki değişimin \% 22,9'nu açıkladığı görülmüştür. Bu bulgudan hareketle deney grubunda uygulanan dönüşümsel öğrenme kuramına dayalı çevre eğitimin kontrol grubuna uygulanan geleneksel öğretim yöntemine göre çevre sorunlarına yönelik tutum üzerine daha etkili olduğu söylenebilir.

Çevreye yönelik inançla ilgili bulgular incelendiğinde deney grubunun çYiö sıra ortalaması 17,79; kontrol grubunun çYiö sıra ortalaması 11,21'dir. Mann Whitney U testi sonuçları çYiö puanlarının deney grubu lehine anlamlı olarak değiştiğini görülmektedir $(U=52,00 ; p<0,05)$. Eta Kare sonucu deney ve kontrol gruplarının ÇYiö puan ortalamaları arasındaki bu anlamlı farklılı̆ın oluşmasında dönüşümsel öğrenme yaklaşımının \% 21, $6^{\prime}$ lık bir etkiye sahip olduğunu göstermektedir. Eta Kare değeri oluşan bu farkın tesadüfi olmadığını göstermektedir. Bu bulgu çevreye yönelik inançların belirlenmesinde dönüşümsel öğrenme kuramına dayalı çevre eğitiminin geleneksel yönteme göre daha etkili olduğunu ortaya koymaktadır.

Çevre duyarlı davranışla ilgili bulgulara göre, deney grubunun ÇDDÖ sıra ortalaması 18,75; kontrol grubunun ÇDDÖ sıra ortalamasının 11,04'tür. Mann-Whitney $U$ testi sonucuna göre ÇDDÖ son test puanları arasındaki farklılık deney grubu lehine istatistiksel olarak anlamlıdır $(U=38,50 ; p<0,05)$. Eta Kare analizi sonucunda, deney grubundaki değişimin kontrol grubundaki değişimden istatistiksel olarak anlamlı miktarda daha fazla olduğu görülmektedir. 
Deneysel işlemin, çevreye duyarlı davranışlardaki değişimin \%18,3'nü açıkladığı anlaşılmaktadır. Bu bulgu çevreye duyarlı davranışlar üzerine dönüşümsel öğrenme kuramına dayalı çevre eğitiminin geleneksel yönteme göre daha etkili olduğu şeklinde vurgulanabilir.

Araştırmanın üçüncü alt problemi "Dönüşümsel çevre eğitimi uygulamaları sonunda deney grubunun çevreye sorunlarına yönelik bilgi, tutum, inanç ve davranışlarında meydana gelen değişiklikler nelerdir?" şeklinde belirlenmiştir. Tablo 5 'te deney grubu ile yapılan görüşmelerden elde edilen bulgular sunulmuştur.

Tablo 5: Deney Grubunda Meydana Gelen Değişikliklere Ait Frekans Ve Yüzdeler

\begin{tabular}{|c|c|c|}
\hline Değişiklikler & Frekans (f) & Yüzde (\%) \\
\hline \multicolumn{3}{|l|}{ Çevre bilgisi değişiklikler } \\
\hline Çevre bilgisi artış & 6 & 86 \\
\hline Yeni kavramlar & 4 & 57 \\
\hline Çevre bilgisi detay & 3 & 42 \\
\hline \multicolumn{3}{|l|}{ Çevreye yönelik inanç değişiklikler } \\
\hline $\begin{array}{l}\text { Gelecekte çevre daha iyi olacak } \\
\text { Gelecekte çevre daha kötü durumda } \\
\text { olacak }\end{array}$ & 4 & 57 \\
\hline Küresel ısınmanın etkisi artacak & 3 & 42 \\
\hline Doğada her canlının yaşama hakkı vardır & 2 & 28 \\
\hline Teknoloji her sorunu çözebilecektir & 1 & 14 \\
\hline Doğa insana karşı üstündür & 1 & 14 \\
\hline \multicolumn{3}{|l|}{ Çevreye yönelik tutum değişikler } \\
\hline Çevreye yönelik farkındalık artışı & 5 & 71 \\
\hline Çevreye ilişkin duyarlıık artışı & 4 & 57 \\
\hline Duygusal tepki & 4 & 57 \\
\hline \multicolumn{3}{|l|}{ Çevreye duyarlı davranış değişiklikler } \\
\hline Çevreye duyarlı davranışlarda artış & 6 & 86 \\
\hline Tasarruf yapmak & 5 & 71 \\
\hline Geri kazanım & 5 & 71 \\
\hline Başka insanların çöplerini almak & 3 & 42 \\
\hline İnsanlara bilgi vermek & 3 & 42 \\
\hline
\end{tabular}


Tablo 5'te deney grubunun bilgi değişiklikleri ile ilgili olarak bilgi artışı temasını bildirdikleri görülmektedir (\%86). Ayrıca yeni kavramlar (\%57) ve bilgi detayları teması (\%42) bilgi değişikliğinde vurgulanan temalar arasında yer almaktadır. Bu bulgular ışığında deney grubunun çevre sorunları ile bilgilerinde olumlu değişimlerin olduğu söylenebilir.

Çevre yönelik inanç değişikliği ile ilgili bulgular incelendiğinde çevrenin gelecekteki durumunun daha iyi olacağına yönelik inanç temasının en çok bildirilen tema olduğu ortaya çıkmaktadır (\%57). Çevrenin durumunun gelecekte daha kötü olacağı (\%42), küresel ısınmanın etkisinin artacağı (\%42) temaları da çevreye yönelik inanç değişimi temaları arasında bulunmaktadır. Bu bulgular ışığında dönüşümsel çevre eğitimi sonunda deney grubunun çevreye yönelik inançlarında değişiklikler olduğu görülmektedir.

Çevreye yönelik farkındalık artışı temasının en çok vurgulanan çevreye yönelik tutum değişim teması olduğu anlaşılmaktadır (\%71). Çevreye yönelik duyarlılık artışı (\%57) ve çevreye ilişkin duygusal tepki temaları (\%57) da biyoloji öğretmen adayları tarafından en çok ifade edilen çevreye yönelik tutum temaları arasında bulunmaktadır. Bu bulgular deney grubunun çevre sorunlarına yönelik tutumlarında olumlu değişimlerin olduğu şeklinde ifade edilebilir.

Deney grubunun birçok çevreye duyarlı davranışta bulunduğu görülmektedir. Çevre davranış değişikliği ile ilgili temalara bakıldığında çevreye duyarlı davranış artışı temasının en çok ifade edilen nokta olduğu anlaşılmaktadır (\%86). Bunun dışında tasarruf (\%71) ve geri kazanım (\%71) temalarının da davranışlarla ilgili olarak ortaya çıkan diğer temalardandır. Aşağıda görüşmelerle ilgili alıntı örnekleri sunulmuştur.

D3:"Bilgi düzeyim arttı, birçok yeni kavram öğrendim. Daha önceleri farkında olmadığım birçok şeye karşı daha duyarlıyım. Bu tür eğitimlerle çevrenin gelecekte daha iyi olacağını düşünüyorum. Çevreye duyarlı davranışlarım arttı. Daha önceleri başkasının çöpünü alıp atmazdım. Şuan sınıfta çıkarken çöpleri alıyorum." D7: "Evet birçok değişiklik oldu. Farkında olmadığım birçok şeye dikkat ediyorum artık. Internette çevreyle ilgili videolar izlemeye başladım. Aileme bilgi veriyorum. Annem yağ biriktirmeye başladı mesela."

\section{TARTIŞMA SONUÇ VE ÖNERILER}

Çağımızın en önemli sorunlarından birisi insanoğlunun çevreyi olumsuz bir şekilde değiştirmesidir. Çevreye insan etkisinin önlenebilmesi noktasında pek çok önlem alınmakta ve bu önlemler farklı çevre eğitimi yaklaşımları ile hayata geçirilmektedir. Bu araştırmada da yeni 
eğitim yaklaşımlarından dönüşümsel öğrenme kuramına dayalı çevre eğitiminin öğretmen adaylarının çevre sorunlarına yönelik etkisi konu edinmiştir. Çalışma sonunda elde edilen sonuçlar aşağıda açıklanmıştır.

Kontrol ve deney grubunun uygulama öncesinde; çevre sorunları bilgisi, çevre sorunlarına yönelik tutum, çevreye yönelik inanç ve çevreye duyarlı davranış ön test puanları arasında anlamlı bir farklıık olmadığı, başka bir ifadeyle bu özellikler bakımından deneysel işlem öncesinde iki grubun denk olduğu belirlenmiştir.

Insanların çevreyle ilgili algılarının önemli boyutlarından birisinin çevreyle ilgili bilgilerinin olduğu bildirilmektedir (Palmer, 1998). Uygulama öncesinde çevre bilgisi değişkenine göre birbirine denk olan iki grubun son test sonuçları karşılaştırıldığında deney grubu lehine anlamlı bir farklıık belirlenmiştir. Eta Kare analizi sonucunda deney grubundaki değişimin kontrol grubundaki değişimden istatistiksel olarak anlamlı miktarda daha fazla olduğu görülmüştür. Bu sonuç, çevre eğitiminde dönüşümsel öğrenme kuramına dayalı eğitimin geleneksel yönteme göre daha etkili olduğu şeklinde ifade edilebilir. Deney grubu ile yapılan görüşmeler sınıf dışı öğrenme etkinlikleri, çevre ile ilgili oyunlar, proje, çalışma yaprağı gibi etkinliklerin deney grubunun çevre sorunları ile ilgili bilgi düzeylerinin dönüşmesinde etkili olduğuna işaret etmektedir. Feinstein (2004) yaptığı çalışmada dönüşümsel doğa eğitiminin öğrencilerin yöresel çevre bilgilerini arttırdığı belirlenmiştir. Ulaşılan bu sonuç araştırma sonuçlarıyla paralellik göstermektedir.

Dönüşümsel öğrenme kuramının önemli öğelerinden birisi de insanların duygusal özellikleridir (Neuman, 1996). Kontrol ve deney grubunun çevre sorunları tutum son test puanları karşılaştırıldığında deney grubu lehine anlamlı bir farklılık ortaya çıkmaktadır. Eta Kare sonucunda deney grubundaki değişimin, istatistiksel olarak kontrol grubundaki değişimden daha fazla olduğu görülmüştür. Bir başka deyişle deneysel işlem, çevreye yönelik tutumu arttırmada etkili olmuştur. Bu noktadan hareketle deney grubuna uygulanan dönüşümsel öğrenme kuramına dayalı çevre eğitiminin kontrol grubuna uygulan geleneksel yönteme göre çevre sorunlarına yönelik tutumun belirlenmesinde daha etkili olduğu söylenebilir. Doğa gezisi ve geri kazanım merkezi gezisi gibi sınıf dışı etkinliklerin ve fotoğraf ile video inceleme etkinliklerin deney grubunun çevre ile ilgili farkındalıklarında olumlu değişiklikler oluşturduğu düşünülmektedir. Collins ve diğerleri (2008), yaptıkları çalışmada dönüşümsel öğrenme kuramına dayalı etkinliklerin Afrika'da yerel halkın çevre korumaya yönelik tutumlarına olumlu etkisinin olduğu belirlemişlerdir.Dettman-Easler ve Pease (1999) sınıf dışı öğrenme 
etkinliklerinin öğrencilerin çevreye yönelik tutumlarını anlamlı düzeyde arttırdıklarını belirlemişlerdir.

Mezirow (1996), inancı hareketlere yön veren alıskanlıklar olarak tanımlamıştır. uygulamalar sonunda deney grubunun çevreye yönelik inançlarının kontrol grubuna göre anlamlı bir şekilde arttığı görülmektedir. Eta Kare sonucu deney grubundaki değişimin, istatistiksel olarak kontrol grubundaki değişimden daha fazla olduğuna işaret etmektedir. Dönüşümsel çevre eğitimi sürecinin çevre inancının belirlenmesinde önemli bir etkiye sahip olduğu anlaşılmaktadır. Drama, senaryo, öz değerlendirme gibi etkinliklerin deney grubunun kendilerini sorgulayarak, farklı rollere uygun bir şekilde düşünmelerini sağladıkları ve çevre ile ilgili inançlarının değişiminde olumlu etkiye sahip olduğu düşünülmektedir. Wyneen, Kylee ve Tarrant (2012) yaptıkları çalışmada dönüşümsel öğrenme kuramına dayalı çevre programlarının öğrencilerin çevreye duyarlı davranış, çevre değer ve inançlarının olumlu değişiklikler oluşturduğunu belirlemişlerdir.

Çevreye yönelik duyarlı davranışlar ile ilgili bulgular incelendiğinde dönüşümsel öğrenme kuramına dayalı çevre eğitiminin deney grubunun çevreye yönelik davranışlarını önemli düzeyde etkilediği anlaşılmaktadır. Başka bir ifade ile uygulamalar sonunda deney grubunun çevreye yönelik davranışlarında daha duyarlı oldukları anlaşılmaktadır. Uygulama etkinleri arasında yer alan proje yapma, mavi kapak etkinliği gibi etkinliklerin deney grubunun çevre dostu davranışlarını olumlu şekilde etkilediği düşünülmektedir. D'Amato ve Krasny (2011) tarafından yapılan çalışmada dönüşümsel öğrenme etkinliklerinin öğrencilerin davranışlarında olumlu değişiklikler meydana getirdiği tespit edilmiştir.

Dönüşümsel öğrenme kuramına dayalı çevre eğitimi sürecinde deney grubu, yaşamlarında birçok değişiklik olduğunu belirtmiştir. Çevre ile ilgili farkındalık ve ilgi artışı, çevresel olaylar karşısında korku ve endişe duygusu deney grubunda meydana gelen değişimler arasında yer almaktadır. Geri dönüştürülebilir ürünleri ayırmak, çevreye zarar veren insanları uyarmak, aile ya da arkadaşlara çevre konusunda bilgi vermek, başkasına ait çöpleri almak gibi davranışların eğitim sürecinde deney grubunun kazandığı davranışlar arasında bulunmaktadır. Sonuç olarak; dönüşümsel çevre eğitimi sürecinde deney grubunun çevre sorunları ile ilgili bilgi, tutum, inanç ve çevreye duyarlı davranışlarında olumlu değişikliklerin oluştuğu anlaşılmaktadır.

Çalışma sonucunda elde edilen bulgular ışığında şu önerilere yer verilebilir; 
- Çevre eğitimine yönelik öğretim etkinlikleri planlanırken dönüşümsel öğrenme kuramına yönelik uygulamalara yer verilmelidir. Bu kapsamda doğa yürüyüşleri, fotoğraf ve video gösterileri, haberler, proje sergileri, drama, senaryo gibi öğrenci merkezli etkinliklere önem verilmelidir.

- Doğa gezisi etkinliğinin deney grubunun çevreye yönelik duygularına olumlu etkisi düşünüldüğünde, çevre eğitimi uygulamalarında doğa merkezli bu tür etkinlikler yapılması yararlı olacaktır.

- Çevreye yönelik projelerin deney grubunun çevre ile ilgili bilinç ve farkındalık oluşumunda etkili olduğu düşünüldüğünde, çevre derslerinde bu tür etkinlikler yapılabilir.

- Öz değerlendirme etkinlikleri öğrencilerin kendilerini ile ilgili değerlendirmelerde bulunmalarını sağlamıştır. Öğrencilerin kendileriyle ilgili farkındalıklarının oluşmasında bu tür etkinlikler kullanılabilir.

- Senaryo, fotoğraf ve video inceleme, biyografi yazma gibi yansıtıcı düşünme etkinlikleri çevre ve ekoloji derslerinde öğrencilerin bilgi, tutum, inanç ve davranışlarının ortaya çıkarılmasında kullanılabilir.

- Drama etkinliğinde öğrencilerin hem eğlendiği hem de farklı bakış açıları geliştirdiği düşünüldüğünde bu etkinliğin çevre eğitiminde kullanılmasının yararlı olacağı düşünülmektedir.

- Sınıf dışı etkinliklerinden biri olan geri kazanım gezisinin, geri kazanım bilincinin oluşturulmasındaki etkililiği ortaya çıkmıştır. Çevre eğitiminde bu tür uygulamalara yer verilebilir.

\section{KAYNAKLAR}

Aksay, S. C., Ketenoğlu O. ve Kurt, L. (2005). Küresel Isınma İklim Değişikliği. Selçuk Üniversitesi, Fen Edebiyat Fakültesi Dergisi, 25, 29-41.

Büyüköztürk, Ş. (2002). Sosyal Bilimler İçin Veri Analizi El Kitabı. Ankara: Pegem Yayıncılık.

Collins, T.D., Gaved, M.B., Mulholland, P., Kerawalla, L.J., Twiner, A., Scanlon, E., Jones, A., Littleton, K., Conole, G. ve Tosunoglu, C. (2008). Supporting Location-Based İnquiry Learning Across School, Field And Home Contexts', in Proceedings of the 7 th World Conference on Mobile and Contextual Learning (mLearn-2008), Telford, UK.

Creswell, J.W. (2003). Research design: Qualitative, quantitative, and mixed methods approaches. (2nd ed.) Thousand Oaks: Sage. D'Amato, L. \& Krasny, M. (2011). Outdoor Adventure Education: Applying Transformative Learning Theory To Understanding 
Instrumental Learning And Personal Growth in Environmental. Journal of Environmental Education, 42 (4), 237-254.

Deniş, H. ve Genç, H. (2007). Çevre Bilimi Dersi Alan Ve Almayan Sınıf Öğretmenliği Öğrencilerinin Çevreye İlişkin Tutumları Ve Çevre Bilimi Dersindeki Başarılarının Karşılaştırılması. Mehmet Akif Ersoy Üniversitesi Eğitim Fakültesi Dergisi, 8 (13), $20-26$.

Dettman-Easler, D. ve Pease, J. (1999). Evaluating The Effectiveness Of Residential Environmental Education Programs in Fostering Positive Attitudes Toward Wildlife. The Journal of Environmental Education, 31 (1), 33-39.

Dresner, M. ve Gill, M. (1994). Environmental Education At Summer Nature Camp. The Journal of Environmental Education, 25(3), 3541.

Dunlap, R.E., Van Liere, K.D., Mertig, A .G. ve Jones, R. E., (2000). Measuring Endorsement Of The New Ecological Paradigm: A Revised Nep Scale. Journal of Social Issues. 56 (3), 425442.

Erol, G. H. ve Gezer, K. (2006). Prospective Of Elementary School Teachers' Attitudes Toward Environment And Environmental Problems. International Journal Of Environmental and Science Education, 1, (1), $65-77$.

Feinstein, B. C. (2004). Learning And Transformation In The Context Of Hawaiian Traditional Ecological Knowledge. Adult Education Quarterly, 54 (2), 105-120.

Hesse-Bıber, S. N. ve Leavy, P. (2004). Approaches To Qualitative Research. A Reader On Theory And Practice. Oxford: Oxford University Press.

Hungerford, H. R. ve Volk, T. L. (1990). Changing Learner Behavior Through Environmental Education. The Journal of Environmental Education, 21 (3), 8-21.

Johnson, R.B. ve Onwuegbuzie, A.J. (2004). Mixed Methods Research: A Research Paradigm Whose Time Has Come. Educational Researcher, 33 (7), 14-26.

Jordan, J. R., Hungerford, H. R. ve Tomera, A. N. (1986). Effects Of Two Residential Environmental Workshops On High School Students. The Journal of Environmental Education, 18 (1), 15-23.

Keleş, Ö., Uzun, N. ve Varnacı Uzun, F. (2010). Öğretmen Adaylarının Çevre Bilinci, Çevresel Tutum, Düşünce Ve Davranışlarının Doğa Eğitimi Projesine Bağlı Değişimi ve Kalıcılığının Değerlendirilmesi. Elektronik Sosyal Bilimler Dergisi, 9(32), 384-401.

Köşker, N. ve Karadağ, S. (2012). Coğrafya Eğitiminde Yer Temelli Öğretim Yaklaşımına İlişkin Öğretmen Görüşleri. TSA, 16, (3), 123-137.

McWhinney, W. ve Markos, L. (2003). Transformative Education Across The Threshold. Journal of Transformative Education, 1(1), 16-37.

Mezirow, J. (1994). Understanding Transformation Theory. Adult Education Quarterly, 44 (4), 222-23

Mezirow, J. (1996). Contemporary Paradigms Of Learning. Adult Education Quarterly. 46 (3), 158-172.

Mezirow, J. ve Associates. (2000). Learning As Transformation. San Francisco: Jossey-Bass. 
Milton, B., Cleveland, E. ve Bennett-Gates, D. (1995). Changing Perceptions Of Nature, Self, And Others: A Report On A Park/School Program. Journal of Environmental Education, 26, (3), 32-42.

Neuman, T. (1996). Critically Reflective Learning in A Leadership Development Context. Unpublished doctoral dissertation, University of Wisconsin, Madison, Wisconsin.

O'Sullivan, E. (1999) Transformative Learning: Educational Vision for the 21st Century. London: Zed Books

Oweini, A. ve Houri, A. (2006). Factors Affecting Environmental Knowledge And Attitudes Among Lebanese College Students. Applied Environmental Education and Communication, 5, 95-105.

Palmer, J.A. (1998) Environmental Education in The 21st Century: Theory, Practice, Progress, Promise. London: Routledge

Ramsey, C. E. ve Rickson, RE. (1976). Environmental Knowledge And Attitudes. Journal Environmental Education, 8, 10-18

Sam, N., Sam, R. ve Öngen, K.B. (2010). Üniversite Öğrencilerinin Çevresel Tutumlarının Yeni Çevresel Paradigma Ve Benlik Saygısı Ölçeği İle İncelenmesi. Akademik Bakış Dergisi, 20, 1-16.

Smith-Sebasto, N.J. ve Semrau, H.J. (2004). Evaluation Of The Environmental Education Program At The New Jersey School Of Conservation. Journal of Environmental Education, 36 (1), 3-18.

Şama, E. (2003), Öğretmen Adaylarının Çevre Sorunlarına Yönelik Tutumları. Gazi Üniversitesi Gazi Eğitim Fakültesi Dergisi. 23(2), 99-110.

Williamson, D. ve Lynch-Wood, G. (2001). A New Paradigm For Sme Environmental Practice. The TQM Magazine. 13, (6), 424-432.

Wynveen, C., Kyle, G.T. ve Tarrant, M.A. (2012). Study Abroad Experiences And Global Citizenship Fostering Proenvironmental Behavior. Journal of Studies in International Education. 16, (4), 334-352.

Yılmaz, Y. ve Yılmaz, Y. (2005). Parametrik Olmayan Testlerin Pazarlama Alanındaki Araştırmalarda Kullanılması: 1995-2002 Arası Yayın Taraması. Dokuz Eylül Üniversitesi, Sosyal Bilimler Enstitüsü Dergisi, 7, (3), 177-199. 


\section{SUMMARY}

The resolution of the bad natural conditions depends on avoiding humans errors committed in the past. Avoiding selfish approaches and increasing environmental awareness can only be achieved through novel environmental approaches. Raising environmentally aware individuals and increasing environmental awareness are among the aims of novel environmental approaches. In order to improve the environment, societies must change and a new understanding of environment must be developed. The main element of this change must be the individual. Thus, awareness will be formed in all sections of the society and individual and societal change will be maintained. In this respect, an environmental education based on transformative learning theory which considers all characteristics of individuals is needed. The aim of the present study is to identify the effect of environmental education based on transformative learning theory on pre-service biology teachers' perceptions.

The mixed design was employed in the research design. Case study was employed in the experimental design with control groups Traditional method was applied to the control group while environmental education based on transformative learning model was applied to the experimental group. Qualitative and quantitative techniques were used together and the results were combined at the end of the study. In order to determine the functionality of the activities to be used and the problems in the application process prior to the application, a pilot study was carried out on 20 secondyear biology pre-service teachers in Fall 2012. In the pilot study, biology teachers' opinions related to the activities were obtained and necessary changes were made. In the original study, environmental education based on traditional approach was applied to the control group for 14 weeks and environmental education based on transformative learning theory was applied to the experimental group. Within the scope of transformative learning theory, biography writing and reading, selfevaluation, nature trips, recycling center trip, problem-based activities, scenario activity, game activity, project and exhibition metaphor, topic presentation, and worksheet activities were performed.

The population comprised freshmen pre-service teachers from the Secondary School Biology Education departments at Hacettepe University and Gazi University in Ankara. The sample comprised 28 freshmen pre-service biology teachers studying at Gazi University Faculty of Education Biology Education department at spring 2013. There were 14 pre-service teachers in the control group and 14 pre-service teachers in the experimental group

Environmental Problems Knowledge Test (EPKT), Attitude Towards Environmental Problems Scale (ATEPS), Environmental Beliefs Scale (EBS), Environmentally Friendly Behavior Scale (EFBS), and semi-structured interview form were used as data collection instruments. The environmental problems knowledge test was developed by the researchers and comprised 25 items. As a result of the validity and reliability analyses, the KR 20 value of the EPKT scale was found to be .74 . Attitude Towards Environmental Problems Scale (ATEPS) was used in order to determine pre-service teachers' attitudes 
towards environmental problems. The scale was developed by Şama (2003) and comprised 21 items. ATEPS was of 5-point Likert type and included the options "I definitely disagree", "I disagree", "I am undecided", "I agree" and "I definitely disagree". Of the ATEPS items, 10 were negative and 11 were positive. ATEPS' Cronbach's alpha reliability coefficient was found to be .77 and the scale was had one dimension. "New Ecological Paradigm" scale was used as environmental beliefs scale. The Ecological Paradigm scale was developed by Dunlap et al. (2000) and the adaptation to Turkish, reliability and validity studies were performed by Sam, Sam and Öngen (2010). The Cronbach's Alpha coefficient of the scale was found to be .53 . In order to determine biology pre-service teachers' environmentally-friendly behaviors, the Environmentally Friendly Behavior Scale (EFBS) developed by the researcher was used. As a result of the reliability and validity analysis, the scale's Kaiser-Meyer-Olkin (KMO) coefficient was found to be .789 and Barlett Sphericity test significance was determined to be 0.00 . As a result of the analysis, it was found that the scale has three factors and the total variance explained by these three factors was $61.1 \%$. The reliability coefficient of EFBS was found to be .79 . The qualitative data were assessed by means of Mann-Whitney U test, Wilcoxon Signed Ranks Test and Eta Square in SPSS 18. As for the qualitative data, they were analyzed by means of content analysis and expressed in frequency and percentage while NVivo 10 software was used in the formation of thematic codes.

Prior to the application, no significant differences were observed between the control and experimental groups' pre-test environmental problems knowledge, attitudes towards the environment, and environmentally friendly behavior scores, in other words, the two groups were found to be equal in terms of these features. Significant differences were observed in the experimental group's environmental problems knowledge, attitudes towards the environment, environmentally friendly behavior levels when compared with the control group which was exposed to the traditional method. The interviews performed at the end of the applications revealed that there have been positive changes in the experimental groups' knowledge of environmental problems, environmental attitudes, and environmentally friendly behaviors. In the environmental education process based on transformative learning model, the experimental group stated that there have been many changes in their lives. Environmental awareness, increased environmental interest, fear and worries about environmental events are among the changes observed in the experimental group. Separating recyclable products, warning people who damage the environment, informing family and friends about the environment, taking other people's trash are among the behaviors acquired by the experimental group. In conclusion, it was understood that positive changes were observed in the experimental group's knowledge of environmental problems, attitudes and beliefs during the transformative environmental education. Recommendations have been presented based on the findings. 